Reprod. Nutr. Dévelop., 1983, 23 (3), 493-499.

\title{
The effect of relaxin on in vivo uterine electromyographic activity in the conscious ovariectomized ewe is oestrogen-dependent
}

\author{
Marie-Jeanne PRUD'HOMME, Nadine MARTINAT, G. PICAPER (*)
}

Station de Physiologie de la Reproduction, I.N.R.A., Nouzilly 37380 Monnaie, France.

(*) Service de Médecine nucléaire, C.H.R. La Source, 45046 Orléans Cedex, France.

Summary. Electromyographic (EMG) activity of the uterus was recorded in vivo in 4 conscious ovariectomized ewes treated with oestrogen (one injection of $100 \mu \mathrm{g}$ of oestradiol benzoate). Doses of $500 \mu \mathrm{g}$ of purified porcine relaxin were injected intravenously $12,16,20,24,28$ and $32 \mathrm{hrs}$ after oestrogen treatment. Relaxin had an inhibitory effect on uterine activity between 16 and $32 \mathrm{hrs}$ after oestrogen treatment. Because the period during which relaxin had a biological effect corresponded to the moment when oestrogeninduced uterine activity was maximal, it is suggested that the ability of relaxin to inhibit uterine activity in the ewe is oestrogen-dependent.

\section{Introduction.}

Relaxin is a polypeptide hormone which inhibits uterine activity in a number of species (Schwabe et al., 1978), principally guinea-pig (Porter, 1972) and rat (Porter et al., 1979 ; Cheah and Sherwood, 1981). It has been demonstrated in rat that the biological effects of relaxin can be obtained in ovariectomized animals without oestrogen-priming (Porter et al., 1979 ; Cheah and Sherwood, 1981 ) but that the inhibition by relaxin of oxytocin or prostaglandin $\mathrm{F}_{2 \alpha}$-driven myometrial activity is oestrogen-dependent (Porter et al., 1981a). Porter et al. (1981b) studying ovariectomized ewe, have shown that relaxin inhibits myometrial activity, but the effect of oestrogen priming remains unsolved since the oestrogen treatment given to all the ewes ceased $48 \mathrm{hrs}$ before relaxin injection. The present experiment was carried out to study the effects of oestrogen priming on response to relaxin treatment in the ewe. The experimental design we used has already been described (Rousseau and Prud'homme, 1974) : an oestrogen injection given to ovariectomized ewe induces oestrus and uterine rhythmic electromyographic (EMG) activity composed of bursts of action potentials. This activity appears $12 \mathrm{hrs}$ after oestrogen injection when burst frequency is between 2 and 2.5 per min and increases, reaching a maximal frequency of 3 to 4 per min about 24 hrs after treatment at the beginning of induced oestrus, and then 
decreases. The effect of purified porcine relaxin on uterine EMG activity recorded in conscious ovariectomized ewe was tested at regular intervals during this pattern, that is to say, every 4 hrs between 12 and 32 hrs after oestrogen injection.

\section{Material and methods.}

We used 4 ewes of the "Préalpes du Sud" breed weighing about $50 \mathrm{~kg}$. Uterine EMG activity was measured using platinum electrodes according to the method of Rousseau and Prud'homme (1974). One electrode was implanted in the uterus of each ewe at the time of ovariectomy.

One week after surgery, the ewes received the first of a series of hormonal injections to induce oestrus (Robinson, 1962) : one daily intramuscular injection of $25 \mathrm{mg}$ of progesterone for 5 days, $10 \mathrm{mg}$ on the 6 th day and $100 \mu \mathrm{g}$ of oestradiol benzoate $(\mathrm{OB})$ on the 8 th day.

Relaxin was extracted from pregnant sow ovaries and purified by ionexchange chromatography on $\mathrm{CM}$ cellulose according to the technique of Sherwood and O'Byrne (1974). The contents of tubes containing biologically active relaxin (determined by mouse pubic symphysis bioassay) were pooled to form three relaxin preparations, CMB, CMa and CMa'. Since there were no apparent differences in the biological activity of these preparations (biological activity: $2700 \mathrm{U} / \mathrm{mg}$ ) (Picaper et al., 1979), we used a composite of them. $500 \mu \mathrm{g}$ of purified relaxin dissolved in $1 \mathrm{ml}$ of physiological saline was injected into the jugular vein of each ewe 12, 16, 20, 24, 28 and 32 hrs after oestrogen administration.

Uterine EMG activity was recorded continuously in conscious animals on a pen recorder (Beckman) for 11 to $34 \mathrm{hrs}$ after oestrogen injection. The EMG recordings were analyzed in $10-\mathrm{min}$ periods to calculate burst frequency. The data were analyzed using Student's paired t-test.

\section{Results.}

Twelve hours after oestrogen treatment, the rhythmic EMG activity of the uterus was composed of bursts of action potentials. The mean \pm SEM was $20.0 \pm 2.9$ bursts per min. Burst frequency increased with time, its maximum occurring between 16 and $24 \mathrm{hrs}$ after oestrogen treatment in the different ewes. The mean frequency obtained at $20 \mathrm{hrs}(28.5 \pm 5.1$ bursts per $10 \mathrm{~min})$ was maximal, being significantly higher than the mean frequency at $12 \mathrm{hrs}$ after oestrogen treatment $(p<0.05)$. The frequency then decreased.

Uterine activity did not change after intravenous injection of $1 \mathrm{ml}$ of physiological saline.

The effect of relaxin varied with time (fig. 1). Twelve hours after oestrogen administration, burst frequency per $10 \mathrm{~min}$ did not change after relaxin treatment (20.0 vs $21.7 ; p>0.05$ ) (fig. 1a, table 1). Relaxin had an inhibitory effect on burst frequency in all 4 ewes 16, 20 and 24 hrs after oestrogen treatment 
(fig. 1b, c, d). Action potentials disappeared for 1 to $10 \mathrm{~min}$ after relaxin was administered. For example (fig. 2, one ewe), $30 \mathrm{sec}$ after relaxin injection, the action potentials were suppressed for $3.5 \mathrm{~min}$.
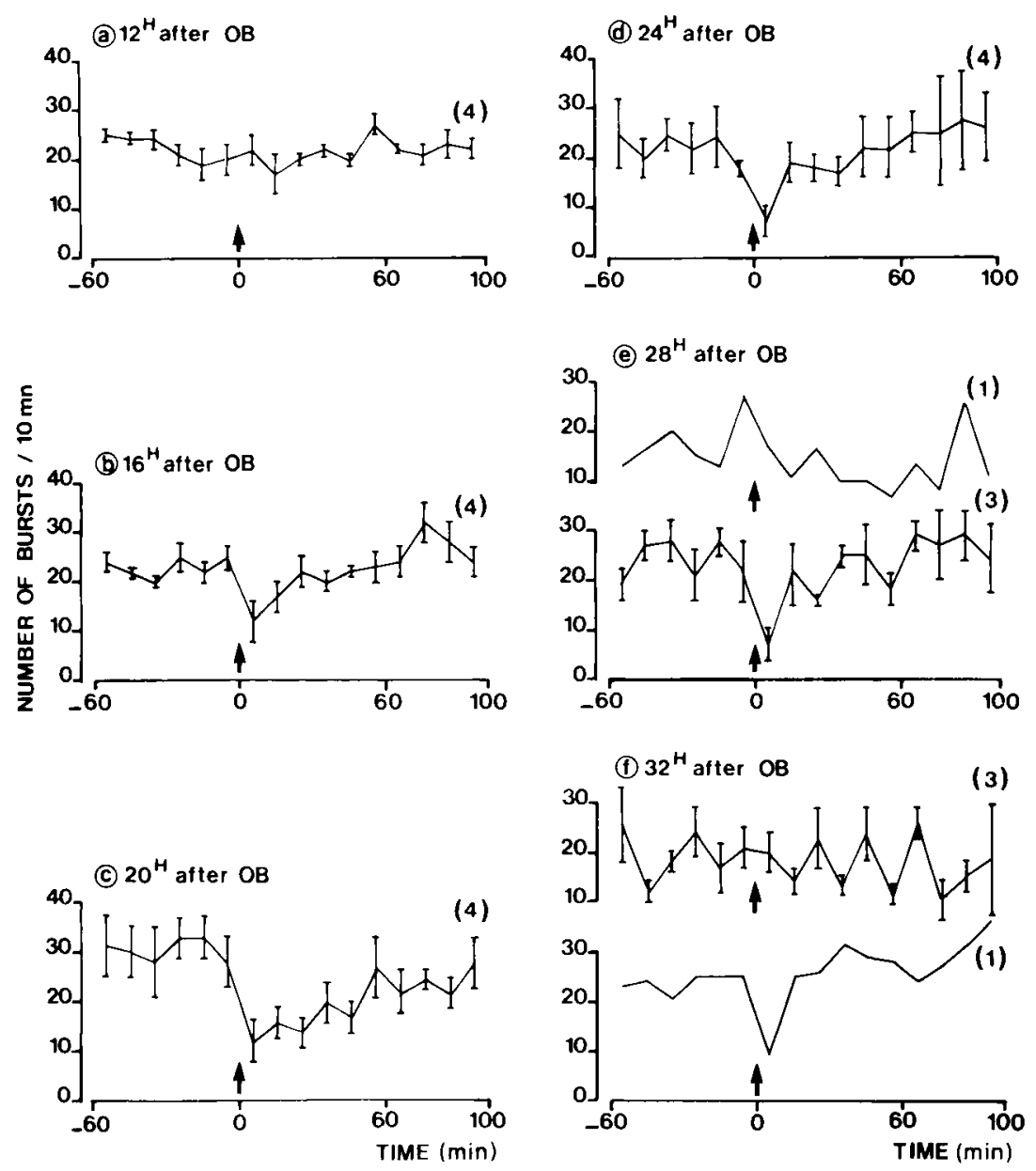

FIG. 1. - Mean frequency of potential bursts in the myometrium during successive 10-min periods for 60 min before until 100 min after intravenous injection of $500 \mu \mathrm{g}$ of porcine relaxin $(\uparrow)$ in 4,3 or 1 conscious ovariectomized ewe(s): 12 (a), 16 (b), 20 (c), 24 (d), 28 (e) and 32 (f) hours after injection of $100 \mu \mathrm{g}$ of oestradiol benzoate (OB). Vertical bars represent $\pm \mathrm{SEM}$.

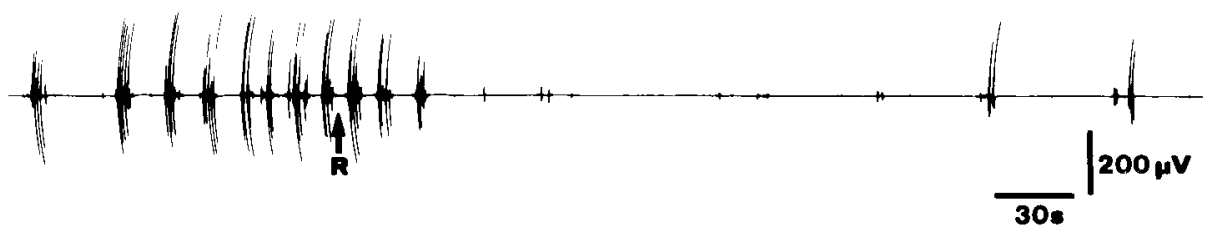

FIG. 2. - The effect of relaxin (R) on EMG activity of the myometrium recorded in one ovariectomized ewe 20 hrs after an injection of $100 \mu \mathrm{g}$ of oestradiol benzoate. 
By 10 min after injection, mean burst frequency per $10 \mathrm{~min}$ had fallen from 24.7 to $12.0(p<0.02), 28.5$ to $12.2(p<0.05)$ and 17.5 to $7.0(p<0.05) 16$, 20 and 24 hrs, respectively, after oestrogen administration (table 1). Inhibitory effects were still observed in 3 out of 4 ewes $28 \mathrm{hrs}$ after this treatment (fig. 1e) ; by 10 min after relaxin injection, mean frequency had fallen from 25.7 to 6.7 bursts per $10 \mathrm{~min}$ ( $p<0.05$; table 1 ). An inhibitory effect was observed in only 1 out of 4 ewes $32 \mathrm{hrs}$ after oestrogen treatment (fig. 1f) ; by $10 \mathrm{~min}$ after relaxin injection, the number of bursts per $10 \mathrm{~min}$ had fallen from 25 to 9 . In the other 3 ewes, mean burst frequency per $10 \mathrm{~min}$ did not change $(21.3 \mathrm{vs}$ $20.0 ; p>0.05$ ) (table 1) before and after relaxin injection.

\section{TABLE I}

Effect of relaxin on burst frequency in the myometrium of ovariectomized ewes at different times after oestrogen treatment

\begin{tabular}{|c|c|c|c|c|c|}
\hline \multirow{2}{*}{$\begin{array}{c}\text { Time }(\mathrm{h}) \text { after } \\
\text { oestrogen treatment }\end{array}$} & \multirow{2}{*}{$\begin{array}{l}\text { Number } \\
\text { of ewes }\end{array}$} & \multicolumn{2}{|c|}{$\begin{array}{l}\text { Mean burst frequency } \\
\text { per } 10 \mathrm{~min} \pm \text { SEM }\end{array}$} & \multirow[b]{2}{*}{ SED } & \multirow{2}{*}{$\begin{array}{l}\text { Statistical } \\
\text { difference }\end{array}$} \\
\hline & & $\begin{array}{l}\text { For } 10 \mathrm{~min} \text { before } \\
\text { relaxin injection }\end{array}$ & $\begin{array}{l}\text { For } 10 \text { min after } \\
\text { relaxin injection }\end{array}$ & & \\
\hline 12 & 4 & $20.0 \pm 2.9$ & $21.7 \pm 3.4$ & 1.2 & $P>0.05$ \\
\hline 16 & 4 & $24.7 \pm 2.2$ & $12.0 \pm 4.5$ & 2.8 & $\mathrm{P}<0.02$ \\
\hline 20 & 4 & $28.5 \pm 5.1$ & $12.2 \pm 4.2$ & 4.5 & $P<0.05$ \\
\hline 24 & 4 & $17.5 \pm 1.2$ & $7.0 \pm 2.8$ & 2.8 & $\mathrm{P}<0.05$ \\
\hline 28 & 3 & $25.7 \pm 3.7$ & $6.7 \pm 2.8$ & 4.4 & $P<0.05$ \\
\hline 32 & 3 & $21.3 \pm 4.7$ & $20.0 \pm 4.0$ & 6.6 & $P>0.05$ \\
\hline
\end{tabular}
test.

SED : Standard error of the difference ; statistical difference was tested using Student's paired t-

The duration of the inhibitory effect was determined by the time required for myometrial activity to return to its normal rhythm after relaxin injection, i.e. the period during which burst frequency was statistically lower. This duration depended on the time after oestrogen treatment (fig. 3). On an average, the inhibitory effect increased until $20 \mathrm{hrs}$ after oestrogen treatment, i.e. the moment when burst frequency was maximal. Its duration then decreased, and the effect was markedly reduced or zero, 28 and $32 \mathrm{hrs}$ after oestrogen treatment. Furthermore, figure 3 shows that inhibition lasted longest in the ewe with the highest burst frequency (ewe 4).

A minimum delay of $16 \mathrm{hrs}$ after oestrogen administration was required before relaxin had an inhibitory effect on uterine activity. The biological effect of relaxin ceased between 24 and $32 \mathrm{hrs}$ after oestrogen treatment. This period was shortest (16-24 hrs after oestrogen administration) in the ewe with the lowest burst frequency (fig. 3, ewe 1) and longest (16-32 hrs after oestrogen treatment) in the ewe with the highest burst frequency (fig. 3, ewe 4). 
(1)

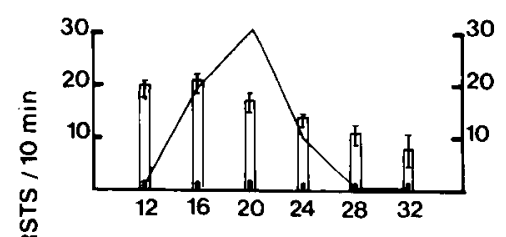

(2)

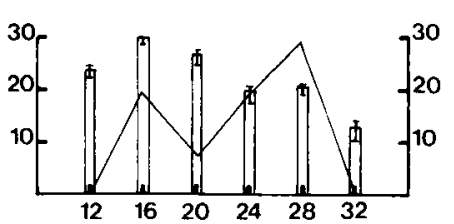

(3)

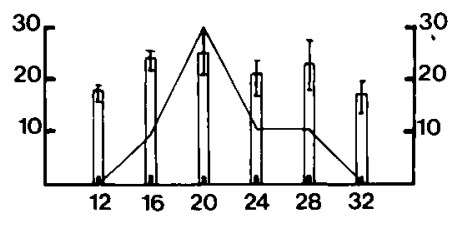

(4)

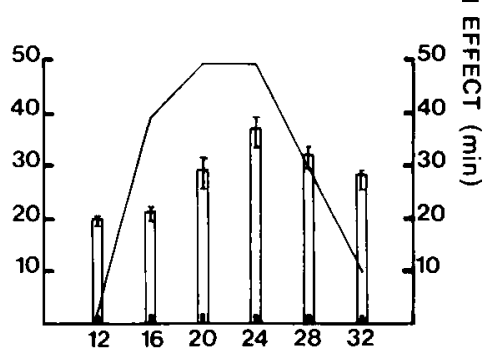

TIME AFTER $O B(h)$

FIG. 3. - Number of potential bursts (mean \pm SEM) in the myometrium per 10 min (columns) calculated from the hour preceding each relaxin injection which was given 12, 16, 20, 24, 28 and 32 hrs after an injection of $100 \mu g$ of oestradiol benzoate (OB) in the 4 ewes studied $(1,2,3,4)$. The continuous lines represent the duration (in $\mathrm{min}$ ) of the inhibitory action of $500 \mu \mathrm{g}$ of porcine relaxin at each injection time.

\section{Discussion.}

In agreement with Porter et al. (1981b), our results show that porcine relaxin exerted an inhibitory effect in ovariectomized ewe. After a single injection of $100 \mu \mathrm{g}$ of oestradiol benzoate under our experimental conditions, relaxin had an inhibitory effect only between 16 and 32 hrs after oestrogen administration. On the other hand, Porter et al. (1981b) reported that this hormone had an inhibitory effect $48 \mathrm{hrs}$ after the end of an oestrogen treatment (several daily injections of $50 \mu \mathrm{g}$ of oestradiol-17 $\beta$ ). These divergent results might be due to different oestrogen treatments.

Although the ewes received several injections of relaxin, the reduced response at 28 and $32 \mathrm{hrs}$ cannot be attributed to refractiveness of the uterus after repeated injections of relaxin since the response increased from the 1st to the 3rd injection, and the decline in response appeared only after the 3rd or 4th injection.

The change in the inhibitory effect of relaxin with time and the fact that the biological effect of relaxin appeared when oestrogen-induced uterine activity was 
maximal, suggests that the ability of porcine relaxin to inhibit in vivo uterine activity in ovariectomized ewe is oestrogen-dependent. These data further indicate that the strongest inhibition due to relaxin was associated with the highest increase in uterine activity after oestrogen treatment; this permits us to suppose that myometrial sensitivity to relaxin increased owing to the action of oestrogen. This increase could be a result of variations in myometrial relaxin receptors since the number of receptors in sow (Bryant-Greenwood et al., 1981) and rat (Mercado-Simmen et al., 1982) increases after oestrogen administration. The minimal delay of $16 \mathrm{hrs}$ probably corresponded to the time needed for the induction or increase of these receptors. Alternatively, this delayed response may be attributed to an effect of progesterone pre-treatment.

The results in ewe are different from those found in rat since, in the latter, the biological effect of relaxin can be obtained in ovariectomized animals without oestrogen-priming (Porter et al., 1979 ; Cheah and Sherwood, 1981).

These results demonstrate that relaxin may exert an effect on the ovariectomized ewe when oestrus is artificially induced. However, as there is no evidence that relaxin is produced in ewe, the putative physiological role for relaxin on ovine myometrial activity remains speculative.

Reçu en juin 1982.

Accepté en novembre 1982.

Acknowledgements. - The authors wish to thank G. Coutherut for technical collaboration, M. Batailler for drawing the graphs, M. Terriot for the photographic reproduction, the secretary for typing the manuscript and G. Montgomery for help with the English translation.

Résumé. L'effet de la relaxine in vivo sur l'activité électromyographique de l'utérus de la brebis ovariectomisée est dépendant des œstrogènes.

L'activité électromyographique (EMG) de l'utérus est enregistrée in vivo chez l'animal éveillé, chez 4 brebis ovariectomisées traitées par les œestrogènes (une injection de $100 \mu \mathrm{g}$ de benzoate d'œstradiol). Des doses de $500 \mu \mathrm{g}$ de relaxine porcine purifiée sont administrées par voie intraveineuse $12,16,20,24,28$ et 32 heures après le traitement œstrogénique. La relaxine a un effet inhibiteur sur l'activité utérine entre 16 et 32 heures après le traitement œstrogénique. Comme la période durant laquelle la relaxine exerce son effet biologique correspond au moment où l'activité utérine induite par les œestrogènes est maximale, il est suggéré que la capacité de la relaxine à inhiber l'activité utérine chez la brebis est sous la dépendance des œstrogènes.

\section{References}

BRYANT-GREENWOOD G. D., MERCADO-SIMMEN R., UENO M., YAMAMOTO S., 1981. Relaxin receptors in the porcine myometrium and cervix. Biol. Reprod., 24, Suppl. 1, 61 A.

CHEAH S. H., SHERWOOD O. D., 1981. Effects of relaxin on in vivo uterine contractions in conscious and unrestrained estrogen-treated and steroïd-untreated ovariectomized rats. Endocrinology, 109, 2076-2083. 
MERCADO-SIMMEN R. C., BRYANT-GREENWOOD G. D., GREENWOOD F. C., 1982. Relaxin receptor in the rat myometrium : regulation by estrogen and relaxin. Endocrinology, 110, 220-226.

PICAPER G., MARTINAT N., DUBOIS M. P., 1979. Dosage radioimmunologique de la relaxine. J. Physiol. Paris, 75, 31A.

PORTER D. G., 1972. Myometrium of the pregnant guinea pig: the probable importance of relaxin. Biol. Reprod., 7, 458-464.

PORTER D. G., DOWNING S. J., BRADSHAW J. M. C., 1979. Relaxin inhibits spontaneous and prostaglandin-driven myometrial activity in anaesthetized rats. J. Endocr., 83, 183-192.

PORTER D. G., DOWNING S. J., BRADSHAW J. M. C., 1981a. Inhibition of oxytocin -or prostaglandin $\mathrm{F}_{2 \alpha}$-driven myometrial activity by relaxin in the rat is oestrogen-dependent. J. Endocr., 89, 399-404.

PORTER D. G., LYE S. J., BRADSHAW J. M. C., KENDALL J. Z., 1981b. Relaxin inhibits myometrial activity in the ovariectomized non-pregnant ewe. J. Reprod. Fert., 61, 409-414.

ROBINSON T. J., 1962. Comparative studies of several gonadotrophin, progestin and oestrogen treatments in the anoestrus ewe. J. Endocr., 24, 33-51.

ROUSSEAU J. P., PRUD'HOMME M. J., 1974. Etude électromyographique de la motricité de I'utérus chez la brebis. Action des hormones. Ann. Biol. anim. Bioch. Biophys., 14, 67-85.

SCHWABE C., STEINETZ B., WEISS G., SEGALOFF A., Mc DONALD J. K., O'BYRNE E. M., HOCHMAN J., CARRIERE J., GOLDSMITH L., 1978. Relaxin. Recent Progr. Horm. Res., 34, 123-211.

SHERWOOD O. D., O'BYRNE E. M., 1974. Purification and characterization of porcine relaxin. Arch. Bioch. Biophys., 160, 185-196. 